\title{
IMPACT OF FLOOD INDUCED MIGRATION ON LIVELIHOOD AND GENDER RELATION: A STUDY ON CHILMARI, KURIGRAM
}

\author{
Md. Mahabub. Chowdhury \\ Lecturer, Department of Development Studies \\ Hajee Mohammad Danesh Science \\ and Technology University, \\ Dinajpur-5200, Bangladesh.
}

\begin{abstract}
The aim of this study is to investigate the impact of flood induced migration on people's livelihood and gender relations within households. Kurigram is the severely poverty affected and one of the most disaster prone districts of Bangladesh. Different studies show that people of this district face disasters like flood, river bank erosion, extreme cold and cyclones every year. Chilmari (a subdistrict of Kurigram) is known as one of the most flood affected areas of the district. To escape the adverse impact of flood, people use to migrate both permanently and temporarily to nearby and far cities and towns in search of livelihood. Using qualitative research techniques including semi-structured interview, focus group discussion, informal group discussion, conversational exchange and case study method, this study revealed that people migrate permanently and temporarily to escape flood in search of alternative livelihood which has an impact on their livelihood such as a rise in income and alternative earning source during flood and gender relations such as changed role of men and women, women's access to decision making and their mobility compare to the male counterparts as well. The findings of this study will help the policy makers, development experts and concerned stakeholders to understand the insights and act accordingly.
\end{abstract}

Keywords - Flood, Gender Relations, Livelihood, Migration

\section{INTRODUCTION}

Bangladesh is a flood prone country. One of the core challenges that Bangladesh faces every year is the devastating impact of floods causing huge amounts of loss in a diverse range of sectors. In some of the years, One third of the country goes under the water. In recent years, a similar magnitude of flood and its devastating impact on livelihood, housing, education, health and food security of millions of people have been noticed. Kurigram has been the most affected district. Even in

\author{
Marjina Masud \\ Gender Specialist - SHOW \\ Plan International Bangladesh, \\ Rangpur Divisional Office \\ House 272, Road 01, G. L. Roy Road \\ Purba Kamal Kachna, Rangpur, Bangladesh
}

2020, people of Kurigram have seen a devastating flood causing huge damage and sufferings. Kurigram is the poorest district in the country (The Business Standard, 16 May 2020). The household and expenditure survey by the Bangladesh Bureau of Statistics (BBS) reports that Kurigram is the most poverty affected district of Bangladesh having a poverty rate of 70.8 percent (The Business Standard, 16 May 2020). At least 150,000 people marooned in Kurigram due to the flood (Dhaka Tribune, 29 June 2020). Chilmari is one of the severely flood affected areas of Kurigram. People of Chilmari face immense loss every year. In 2020, the Brahmaputra River was flowing $45 \mathrm{~cm}$ above the danger mark at Chilmari point (United News of Bangladesh, 13 July 2020).

Flood situation hampers people's livelihood leaving people with uncertainties and difficulties financially and socially. Extreme flood leads to damage to the crop fields and the resulting river bank erosion causes decrease in the number of cultivable land. Most of the people including men and women of this region are poor and they are greatly dependent on their income as labor in the agricultural sector. To escape the impact, people of the affected area of Kurigram use a technique of seasonal migration so that at least one of the family members goes to nearby towns and cities to find alternative informal work including daily laborer and rickshaw pulling in order to support their family during the crisis.

The objectives of the research is to assess the impact of flood induced migration on the livelihood of flood affected people and to trace out the impact of flood induced migration on women's role, status, occupation, workload and decision making power compared to their male counterparts.

\section{LITERATURE REVIEW}

Bangladesh is well-known for being flood affected every year. Bangladesh undergoes and faces massive flooding every year. Because of the uncertain climatic condition and heavy monsoon rain, some reports suggest, one third of Bangladesh goes under flood water most often. millions of lives are affected 


\section{International Journal of Engineering Applied Sciences and Technology, 2020 \\ Vol. 5, Issue 5, ISSN No. 2455-2143, Pages 1-7 \\ Published Online September 2020 in IJEAST (http://www.ijeast.com)}

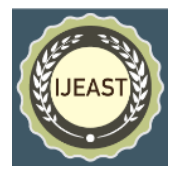

by the devastating impact. Bangladesh is crisscrossed by 230 rivers, including 53 shared with India and the heavy rains have swollen two main Himalayan river systems - the Brahmaputra and the Ganges - that flow through India and Bangladesh (Al Jazeera, 14 July 2020).

In the 2020 flood, Al Jazeera reports that at least 1.5 million people are affected, as rivers threaten to burst their banks. Bangladesh's vulnerability due to flood has been widely acknowledged in research and study. Bangladesh faces flood every year and the situation has become critical in recent years.

According to study, one of the major reasons behind this flood affectedness is climate change. According to the Climate Change Vulnerability index (2014) Bangladesh ranks first as the most affected country in South Asia in respect to being the victim of impact of climate change. Every year Bangladesh has to face extreme natural disasters and calamities. Rahman (2013) cites that Bangladesh has become synonymous with climate change induced natural disasters. Stern (2007) states that Bangladesh is going to be one of the most vulnerable countries in the world as the consequences of climate change.Current estimate suggests that the temperature of Bangladesh will increase up to one to five degrees by the year 2100 (Khatun, 2013). Khatun (2013) narrates that if precipitation increases, which are more likely in the case of Bangladesh, she will receive more water during monsoon and less water during winter causing floods and droughts respectively. The World Bank (2018) report states that if the temperature increases by four degrees, the production of two major crops will reduce to a one-third. Besides, its impact will also lead to more natural disasters and Bangladesh is experiencing the reality of that.

In a study titled "Climate Change, Disaster and Gender Vulnerability: A Study on Two Divisions of Bangladesh", Rahman (2013) also narrates that Climate change is causing more severe and more frequent storms and drought, resulting in changes in timing which brings about changes in the pattern of seasonal cyclones, seasonal diversity and quantity of rainfall which cast havoc on agricultural production. One million people are displaced every year because of riverbank erosion in the Bangladesh (Elahi,1990). Elahi (1990) also argues that flood and riverbank erosion are two major environmental disasters that Bangladesh experienced. Flood and riverbank erosion often dislocates cultivable land and human settlements, and it also destroys agricultural crops massively, disrupts roadlinkages and communication infrastructure of the country (Rahman, 2014). Rahman (2013) claims that even in a normal year, almost half of the country undergoes flood and inundation bringing flood related risks, and more than ten million people live in areas of high risk, lead landless, impoverished fishermen, and tenant farmers remain most exposed to natural hazards.

Study and reports show that Kurigram is the poorest district in Bangladesh having a poverty rate of 70.8 percent (The Business Standard, 16 May 2020). The vulnerability flood affectedness increases along with the extreme poverty and people go through unbearable sufferings and hardship. Mollahet. al. (2011) states that temporary migration as an adaptive response to climate stress is already apparent in many areas. Mollahet. al. (2011) added that the picture is nuanced where the ability to migrate is a function of mobility and resources in terms of both financial and social factors. In Bangladesh migration from rural to urban areas has become a livelihood strategy adopted by an increasing number of families who migrate to the city in search of better employment opportunities (Farhana et al., 2012). In Bangladesh, many poor and landless migrants are forced to migrate to support themselves or their families (Ahmad, 2004). Ahmed (2015), in his study titled "Application of Scientific and Indigenous Knowledge for Flood Management in Northwest Bangladesh" states that chronic poverty and hunger along with frequent natural disasters particularly flood and river erosion further add to the uncertainties in people's lives. To avoid the extreme consequences resulting from severe flooding and poverty, people try to migrate in nearby or far cities and own in search of livelihood. This migration may be permanent or temporary. Study shows that a large number of people migrate every year. In Bangladesh, severe flooding caused three-thousand people to leave their residences daily, heading to Dhaka, the capital (Black et al., 2008)

This type of migration is reported to have an impact on people's livelihood and gender relations. Gender relations possess what status men and women should hold in relation to each other. The flood induced migration may have an impact on the existing gender relation within the household as the livelihood pattern changes along with migration.

\section{RESEARCH METHODOLOGY}

Research methodology is a defined way to be systematically solving the research problem. Research methodology has been regarded as a science of how research is conducted and done. In research methodology it is studied that the various steps that are generally aborted by a researcher in studying the research problem along with the logic behind them. This study is exploratory in nature and therefore tools of qualitative research methodology are very important and relevant in this regard. It includes structured questionnaires, respondents have to choose between options available or have to provide specific numerical information. The final report usually has a set structure that deductively tries to examine theories or assumptions.

In this study a qualitative approach will be used to assess the impact of flood induced migration on the livelihood of flood affected people and to trace out the impact of flood induced migration on women's role, status, occupation, workload and decision making power compared to their male counterparts. 


\section{International Journal of Engineering Applied Sciences and Technology, 2020 \\ Vol. 5, Issue 5, ISSN No. 2455-2143, Pages 1-7 \\ Published Online September 2020 in IJEAST (http://www.ijeast.com)}

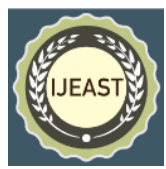

\section{A. Primary Data-}

Primary data has been collected in the research setting. Purposive sampling method will be employed in selection of respondents and study areas. Semi-structured interviews, informal group discussion, focus group discussion, in-depth interview, conversational exchange and case study method are used to collect data.

\section{B. Secondary Data-}

National and international report on COVID-19 and flood in Bangladesh, journal articles, books, record and report of government and non-government organizations, newspaper and television are the secondary sources of data of this study.

\section{Population-}

As this research intends to study the impact of flood induced migration on livelihood of flood affected people and gender roles as well, flood affected people are the key respondents of this study.

\section{Sampling Procedure-}

In this study heterogeneous purposive sampling was done to get as much insights as possible regarding the insights of affectedness of flood, coping and adaptive strategy in connection with alternative livelihood, flood induced migration, and impact of flood induced migration on people's livelihood and gender relation. A sample of 100 respondents who are flood affected participated in this study. In addition, 8 women for one focus group discussion and 4 men and 4 women for another focus group discussion were also selected using a purposive sampling method.

\section{E. Study Setting-}

The study is conducted in Chilmari Upazila of Kurigram district. According to Banglapedia, Chilmari Upazila has a area of $224.97 \mathrm{sq} \mathrm{km}$ Chilmari is one of the most flood prone upazila of Kurigram district. There are several water bodies including Brahmaputra river, Chaslar Beel, Udnar Beel, Magurar Beel, Horinnar Bandha Beel, Shouldhukrir Beel and Pedi Theorar Beel (Banglapedia, 2020). Every year, people face acute flooding and sufferings. In the 2020 flood, Brahmaputra River in Kurigram has been flowing $73 \mathrm{~cm}$ above the danger level at Chilmari point (The Daily Star, 18 July 2020).

\section{F. Data Collection Techniques-}

Semi-structured Interview: Semi-structured interview helps to get both necessary qualitative and quantitative information which is easier to analyze. This method is used in this study. Semi-structured interviews of the respondents have been conducted to know and understand the insights of the trend of flood induced migration, its impact on their livelihood and gender relations. Total 100 respondents were interviewed using a semi-structured questionnaire.

Focus Group Discussion: Focus group discussion is a structured discussion used by the researcher to obtain in-depth information from a group of people on a particular issue or about a particular topic. In this study Focus group discussion has been conducted with the group of individuals who have been experiencing the flood and its devastating impact, migrated to flee from flood and in search of alternative livelihood. Two Focus group discussion were taken where one is with women and the other one is with women and men.

Conversational Exchange: Conversational Exchange is a common method of data collection in qualitative research. It is an open-ended method of qualitative data collection. This method assists in building rapport with respondents. Researchers are able to take note or record the conversation as per the prior permission of the respondents in order to collect information which helps them to gather and better understand the insights of a particular issue. This method has also been used in this study.

Informal Group Discussion: Informal group discussion helps the researcher to capture the collective view of the respondent especially on common issues. Informal group discussion has been used in this research as well.

Case Study Method: Case Study Method is a qualitative research method which helps the researcher to gather in-depth and descriptive information about specific issues, cases, events, entities, or cases and which is collected, organized, interpreted, and presented in a narrative format as well. This method is used in this study.

\section{G. Method of Data Analysis-}

The collected data was analyzed following qualitative data analysis techniques including categorizing data in order to classify, summarize and tabulate data, transcription and reformation of stories and experiences of respondents and discourse analysis. Microsoft Excel has been used for statistical computation in this research as well.

\section{RESULTS AND FINDINGS}

\section{A. Background Information of Respondents}

The education among the people is poor. Twenty one percent respondents did not go to school in their lifetime and $15 \%$ of them can sign only. Sixty eight percent respondents were found to have primary education only. In response to the question of why their education is so poor, respondents replied that because of their poor socio-economic condition, they barely had the 
option to either go to school or continue education. Some of the respondents reported that their parents were so backdated that they did not understand the importance of education. A respondent mentioned that "from the very beginning, we were told to be a helping hand in the family and no one of my family had ever emphasized the need of our education. As a result, we did not get the chance to go to school". In case of women respondents, they mentioned that girls were expected to get married at a very early age back then and this has deprived their educational attainment.

Table 1: Background Information of Respondents

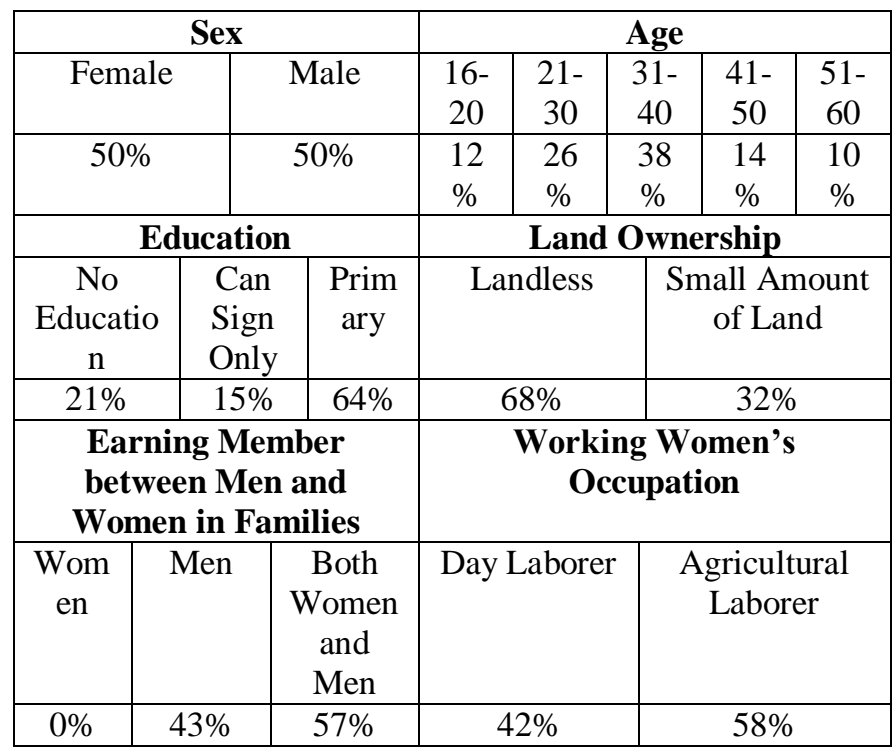

They are found to be having very small amounts of land. Sixty eight percent are landless and $32 \%$ are found to own a small amount of land. Thus only $20 \%$ live on their own land and the rest $80 \%$ live on dams, government land and roadside land. Only $22 \%$ of women own land compared to men. It is observed that $63 \%$ live in 'Jhupri' house and rest $37 \%$ live in bamboo made houses. All houses are covered with Tin sheds as roofs. Forty two percent lost their house and $30 \%$ lost their cultivable land due to river bank erosion caused by flood. Most recently, $20 \%$ of the respondents lost their crops due to flood and river bank erosion. It is found that $53 \%$ respondents own cattle.

Fifty seven percent respondents mentioned that both men and women work for the subsistence in the family. Among them, $42 \%$ women work as a day laborer and $50 \%$ as agricultural laborer. These working women can work only for six months in a year. In the rest six months, they remain workless as flood disrupts their working and earning opportunities. During the flood, men can go out even in far villages, towns and cities in search of alternative livelihood.

\section{B. Flood Induced Migration Pattern}

This study found that people move from their village to nearby and far villages, cities and towns to escape the adverse impact of flood especially in search of livelihood. Men of the flood affected families move to nearby cities and towns to earn a livelihood and send it back to their families. Hundred percent of the respondents have reported that their male family members go to nearby and far cities and towns during the flood time every year.

Table 2: Migration Pattern

\begin{tabular}{|c|c|}
\hline $\begin{array}{l}\text { At Least One Individual } \\
\text { Migrates from Family }\end{array}$ & $55 \%$ \\
\hline $\begin{array}{l}\text { Two Individual Migrate } \\
\text { from Family }\end{array}$ & $45 \%$ \\
\hline
\end{tabular}

Fifty five percent families have at least one individual who migrates during the flood and $45 \%$ families have two individuals who migrate during the flood. No family was found to have female members who migrated during the flood. All respondents mentioned that they migrated as there was no scope for them to earn their subsistence during the flood. Both the head of the households and son are reported to migrate in all these cases. In case of sons, they take such decisions to migrate during the flood leaving their education and schooling behind. In any cases, they barely can continue their education again. But women cannot move like men as they look after their family and take care of everyone. Limited social mobility also hindrances women's scope to go out in search of livelihood during flood.

\section{Table 3: Duration of Migration}

\begin{tabular}{|l|c|}
\hline Migrated for Whole Year & $63 \%$ \\
\hline $\begin{array}{l}\text { Migrated for Only the Flood } \\
\text { Season }\end{array}$ & $37 \%$ \\
\hline
\end{tabular}

Among the migrated individuals, $63 \%$ migrated for the whole year and $37 \%$ migrated for only the flood season. Thus, there is a difference among the types of work they do.

Table 4: Type of Work

\begin{tabular}{|l|l|}
\hline Work in Garments Factory & $43 \%$ \\
\hline Work as a Day Laborer & $16 \%$ \\
\hline Work as a Rickshaw Puller & $41 \%$ \\
\hline
\end{tabular}

Forty three percent migrated individuals work in garments factories in Gazipur and Savar whereas $61 \%$ work as a rickshaw puller in different towns and cities including Kurigram, Rangpur and Dhaka as well. The rest $16 \%$ work as day laborers 
during their migration in different locations. It is found that $60 \%$ of migrated sons of the family under this research are between the ages of 16 to 20 and $40 \%$ are between the ages of 21 to 24. It indicates that a majority of them migrate during floods at such an age when they are required to continue their schooling. It is also found that $27 \%$ of them already got married before the age of 20. Child marriage among the boys is found as well.

\section{Impact of Migration of Family Members on Livelihood}

It is found that this type of migration has a significant impact on the livelihood condition of the flood affected people. Respondents reported that they see improvement in their living condition.

\section{Family Income-}

\section{Table 5: Increase in Family Income}

\begin{tabular}{|c|c|c|}
\hline & Before Migration & After Migration \\
\hline $\begin{array}{c}\text { Migrating One } \\
\text { Member from the } \\
\text { Family }\end{array}$ & $\begin{array}{c}\text { 6,000/- to 8,000/- } \\
\text { Per Month }\end{array}$ & $\begin{array}{c}8,000 /- \text { to } 12000 /- \\
\text { Per Month }\end{array}$ \\
\hline $\begin{array}{c}\text { Migrating Two } \\
\text { Members from } \\
\text { Family }\end{array}$ & $\begin{array}{c}\text { 6,000/- to 8,000/- } \\
\text { Per Month }\end{array}$ & $\begin{array}{c}12,000 /- \text { to } \\
16,000 /- \text { Per } \\
\text { Month }\end{array}$ \\
\hline \multicolumn{2}{|c}{} & \multicolumn{2}{|c}{} \\
\hline
\end{tabular}

Respondents reported that their family income has risen after the migration. In case of one family member who migrated recently during the flood, the family members reported that their income has risen from 6000/- to 8000/- per month before migration to $8000 /$ - to $12000 /-$ per month after migration. A respondent mentioned that "our total income has risen after my husband has recently gone to Dhaka to work. Before that we did not have enough options here in Childmari to earn enough to support our family expenditure".

\section{Health Care and Education of the Children}

\section{Table 6: Medical Treatment Seeking Behavior}

\begin{tabular}{|c|c|}
\hline $\begin{array}{c}\text { Government Hospital for } \\
\text { Medical Treatment }\end{array}$ & $71 \%$ \\
\hline $\begin{array}{c}\text { Regular Checkup During } \\
\text { Pregnancy }\end{array}$ & $62 \%$ \\
\hline
\end{tabular}

A significant change in health care seeking behavior reported by the respondents. Seventy one percent mentioned that they have gone to government hospitals recently to seek medical treatment and consult with government doctors. When they were asked about maternal health care, among the 32 pregnancy cases, $62 \%$ responded that they went to regular checkup during pregnancy in nearby community clinics and government hospitals and were able to afford treatments and services after the migration.

The situation of drop-out from school has not significantly improved. Only $17 \%$ are reported to re-send their dropped-out children again in the school.

\section{Water and Sanitation}

Table 7: Setting-up Sanitary Toilet and Tube-Well

\begin{tabular}{|l|l|}
\hline Setting-up Sanitary Toilet & 43 Families \\
\hline Setting-up Tube-well & 39 Families \\
\hline
\end{tabular}

Another important condition is water and sanitation of the respondents where a significant improvement is reported. Sanitary toilets were set-up by 43 families after their family members recently migrated during the flood. Thirty nine cases were found where families were able to set-up tube-well. Both setting-up sanitary toilets and tube-well have enabled them to have better access to water and sanitation.

\section{Impact of Migration of Family Members on Gender Relations}

This research also intends to investigate the impact of flood induced migration on women's role, status, occupation and workload and decision making power compared to their male counterparts. Respondents have mentioned some changes in the existing gender relations.

\section{Gender Roles}

In societies like Bangladesh, there are certain roles, responsibilities, status and temperament are appropriated for men and women. Women are expected to play a role different from men. Respondents have reported a change in the gender roles. Before migration, men were the prime breadwinner whereas $57 \%$ women were the financial contributors in the family in addition to their familial responsibilities such as looking after families, taking care of everyone, cleaning and cooking for everyone. When male members of their families go out during the flood for alternative subsistence, women are left with only the option to be with their family member in flood. They do not also have the option to earn subsistence as there is very limited wage earning opportunity left because of the flood situation. During the dry season, men are mainly responsible to go out to buy household necessities from the local market. But, the migration of male members left women responsible to maintain these responsibilities which are mainly considered as the primary responsibilities of men. This change in role has implications on women's workload as well. Women are primarily responsible to accomplish traditional responsibilities such as cooking, cleaning, rearing and bearing children, taking care of elderly members. The extra workload of maintaining other work in absence of the male members creates extra burden on their shoulder. In such a crisis situation when there is 
shortage of basic resources for survival, women are left alone as the prime responsible person to look after everyone in absence of the male members who migrate in search of alternative livelihood.

Decision Making within the Household, Women's Mobility, and Control over Contraceptive Use

Table 8: Decision Making Regarding Familial Issues

\begin{tabular}{|c|c|c|}
\hline & Before Migration & After Migration \\
\hline $\begin{array}{l}\text { Decision Making } \\
\text { by Women } \\
\text { Regarding } \\
\text { General Familial } \\
\text { Issues }\end{array}$ & $51 \%$ & $70 \%$ \\
\hline $\begin{array}{c}\text { Decision Making } \\
\text { by Women } \\
\text { Regarding } \\
\text { Crucial Familial } \\
\text { Issues } \\
\end{array}$ & $22 \%$ & $32 \%$ \\
\hline
\end{tabular}

Change in role in decision making and access to decision making have also been reported by the respondents in the context of flood induced migration. Fifty one percent mentioned that women had access to general familial issues before the migration whereas $70 \%$ reported that there is improvement of women's access to and control over the decision making regarding general familial issues. One female respondent mentioned that "now my husband asks for my opinion regarding familial issues in almost all cases". A 19\% improvement has been found in this case. In absence of the male member, women are in a position where they have the freedom to take decisions previously only men have that access. In case of crucial familial issues, $22 \%$ respondents reported that they were asked about their opinion before migration. In the context of migration, 32 respondents mentioned that they have access to and control over the decisions regarding crucial familial issues such as buying or selling cattle, livestock, marriage and other financial issues.

Women have also talked about their access to decisions regarding children's education, migration of women like men to earn subsistence to contribute in family, savings, and expenditure of women's own income as well. Women have mentioned that there is no improvement in all these cases before and after migration of male members of their family. Domestic violence is also a critical issue. Women under the study have also talked about their situation in this regard. Sixty two percent women reported that they face violence in their families by their husbands and in laws as well. Because of the absence of their husband, 32 of them reported that they feel relieved during the migration tenure. But, they have recently faced such violence when their husbands came back home. Women were also asked about their access to and control over the decision making in contraceptive use and family planning. They have mentioned there is no improvement in their access to and control over these decisions before and after migration. One female respondent mentioned "I have no say over my pregnancy. I have three children and I was not asked for my opinion whether I want the child now or not".

\section{CONCLUSION}

Bangladesh is a flood prone country. Kurigram as a district and Chilmari as a Upazila (sub-district) are one of the most affected areas of northern Bangladesh. Every year people face unbearable sufferings and difficulties because of the flood. People use several coping strategies to cope with the devastating situation and survive. Insecurity of their livelihood has pushed them to migrate in near and far cities and towns in search of subsistence. The main focus of the study is to understand and explore the impact of flood induced migration on their livelihood and gender relations. This study shows that people migrate to escape the adverse effects of flood on their livelihood. This secures their familial financial necessity and helps them to survive in the crisis situation. The findings of this study also show that flood induced migration creates a positive change in an increase in family income, access to clean water and sanitation and improvement in access to and availing health care services and facilities as well. Added to this, the migration has also found to have an impact on gender relations including women's and men's roles and responsibilities, access to and control over resources and decision making regarding general and crucial familial issues, mobility, decision making over contraceptive use and planning and violence against women. Women have better access to decision making especially general familial issues. At the same time, the findings show that the absence of their husbands and male members creates extra pressure on women's shoulders of both maintaining a lot of responsibilities of maintaining family alone and taking care of children and elderly members, cooking, cleaning and accomplishing other household responsibilities. Issues like violence against women, access to and control over resources, decision regarding contraceptive use and family planning remain unchanged in most of the cases.

\section{ACKNOWLEDGMENT}

The hard work and effort of all field enumerators are appreciated and acknowledged. We also appreciate and acknowledge the support of the local guide in the research setting for his support and assistance during the whole process of data collection and enumeration. We acknowledge the guidance and supervision of senior teachers for their valuable support. 


\section{REFERENCE}

[1] Ahmed, S. (2015). Application of Scientific and Indigenous Knowledge for Flood Management in Northwest Bangladesh. Postgraduate Programs in Disaster Management (PPDM). BRAC University, Dhaka, Bangladesh [Online] Available From: http://dspace.bracu.ac.bd/xmlui/bitstream/handle/10361/4653/ Thesis_Sohel.pdf?sequence=1 [Accessed: 08 June 2020].

[2] Akter, T. (2009). Climate Change and Flow of Environmental Displacement in Bangladesh. Unnayan Onneshan: Dhaka.

[3] AlJazeera. (2020). A Third of Bangladesh Underwater' After Heavy Rains, Flood [Online] Available From: https://www.aljazeera.com/news/2020/07/bangladeshunderwater-heavy-rains-floods-200714133251746.html [Accessed: 19 July 2020] .

[4] Banglapedia. (2020). Chilmari Upazila. [Online] Available From:

http://en.banglapedia.org/index.php?title=Chilmari_Upazila [Accessed: 12 June 2020]

[5] Black, R., Kniveton, D., Skeldon, R., Coppard, D., Murata, A., \& Schmidt V. K. (2008). Demographic and Climate Change: Future Trends and their Policy Implications for Migration. Development Research Center on Migration, Globalization and Poverty. University of Sussex: Brighton.

[6] Business Research Methodology. (2020). Qualitative Data Analysis [Online] Accessed From: https://researchmethodology.net/research-methods/data-analysis/qualitativedata-analysis/ [Accessed: 16 June 2020].

[7] Climate Change Vulnerability Index (2014). [Online] Available From: http://reliefweb.int/sites/reliefweb.int/files/resources/Climate_ Change_Vulnerability_Index_\%202014_Map.pdf [Accessed: 11 June 2020]

[8] Dhaka Tribune. (2020). 150,000 People Marooned in Kurigram as Flood Situation Worsens [Online] Available From: https://www.dhakatribune.com/bangladesh/nation/2020/06/29/ 150-000-people-marooned-in-kurigram-as-flood-situationworsens [Accessed: 11 July 2020].

[9] Dhaka Tribune. (2020). One-third of Bangladesh Under Water in Worst Floods in a Decade [Online] Available From:

https://www.dhakatribune.com/bangladesh/2020/07/15/one-

third-of-bangladesh-underwater-in-worst-flood-in-decade

[Accessed: 19 July 2020].

[10] Elahi, K., \& John, R., (1990). Riverbank Erosion, Flood and Population Displacement in Bangladesh: A Report on the Riverbank Erosion Impact Study. Dhaka: Riverbank Erosion Impact Study, Jahangirnagar University.

[11] Farhana, K. M., Rahman, \& S. A.,Rahman, M. (2012). Factors of Migration in Urban Bangladesh: An Empirical Study of Poor Migrants in Rajshahi City. Bangladesh e-Journal of Sociology, vol. 9, no. 1
[12] Khatun, M. (2013). Climate Change and Migration in Bangladesh: Golden Bengal to Land of Disasters. Bangladesh e-Journal of Sociology, vol. 10, no. 2

[13] Rahman, M. S. (2013). Climate Change, Disaster and Gender Vulnerability: A Study on Two Divisions of Bangladesh. American Journal of Human Ecology. 2(2). P. $72-$ 82

[14] Rahman, S.U. (2014). Impacts Of Flood On The Lives And Livelihoods Of People In Bangladesh: A Case Study Of A Village In Manikganj District. Postgraduate Programs in Disaster Management (PPDM). BRAC University, Dhaka, Bangladesh

[15] Stern, N. (2007). The Economics of Climate Change: The Stern Review. Cambridge University Press: Cambridge.

[16] The Business Standard. (2020). The Poorest Receive the Least Amount of Relief [Online] Available From: https://tbsnews.net/coronavirus-chronicle/covid-19-

bangladesh/poorest-receive-least-amount-relief-82186 [Accessed: 11 July 2020].

[17] The Daily Star. (2020). 3 Lakh Flood-hit People Face Drinking Water Crisis in Kurigram [Online] Available From: https://www.thedailystar.net/flood-in-bangaladesh-2020-3-

lakh-people-face-drinking-water-crisis-1932229 [Accessed: 19 July 2020]

[18] The World Bank. (2018). Bangladesh: Rising Temperature Affects Living Standards of 134 Million People [Online] Available From: https://www.worldbank.org/en/news/press-

release/2018/09/26/bangladesh-rising-temperature-affectsliving-standards-of-134-million-people [Accessed: 15 June 2020].

[19] United News of Bangladesh.. (2020). Flood Situation Worsens in Kurigram. [Online] Available From: https://unb.com.bd/category/Bangladesh/flood-situationworsens-in-kurigram/54559 [Accessed: 16 July 2020]. 